нитного поля. Подобные установки, основанные на ЯМР, используются в национальных метрологических институтах ряда европейских стран.

В основе передачи магнитных единиц магнитным материалам лежит воспроизведение магнитного поля в электромагните, в которое помещается образец магнитного материала, и измерение характеристик образца.

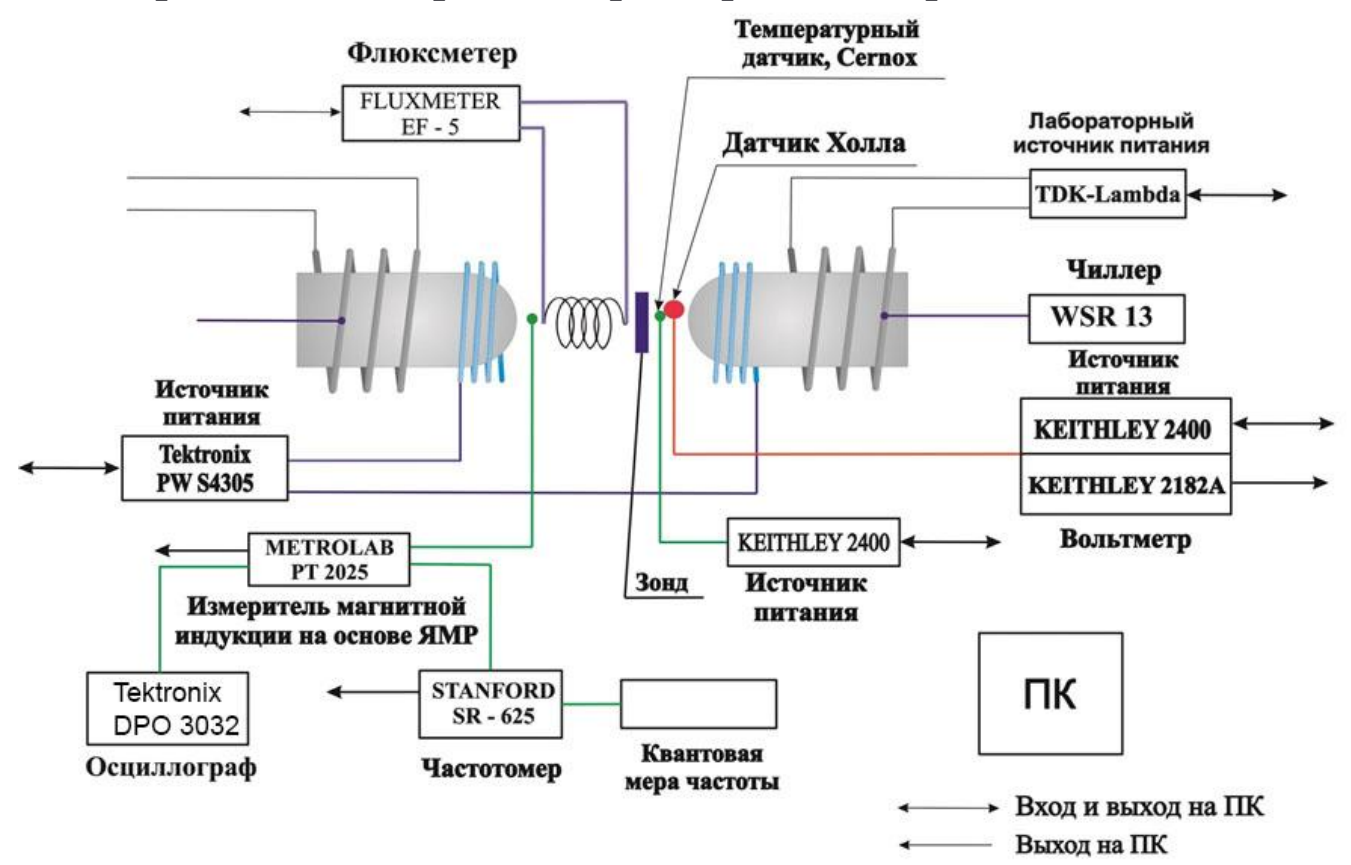

Рис. 1. Структурная схема установки

Разрабатываемый эталон в комплексе со стандартными образцами утвержденных типов позволит решить проблему метрологического обеспечения магнитоизмерительных установок, применяемых для измерения свойств магнитных материалов.

В докладе будет подробно рассказано о средствах измерений, входящих в состав установки и особенностях функционирования установки, а также приведены ее метрологические и технические характеристики.

Работа выполнена при финансовой поддержке ГК 120-151 от 19.06.2015 2.

\title{
USAGE OF LOWPASS FILTERS FOR MINIATURIZATION OF MICROSTRIP BRANCH-LINE HYBRID COUPLERS
}

\author{
Letavin D.A., Mitelman Y.E., Chechetkin V.A.* \\ Ural Federal University, Yekaterinburg, Russia \\ *E-mail: v.a.chechetkin@urfu.ru
}

One of the important trends today is the reduction of the geometric dimensions of microstrip devices. Many researches provide information on the use of a number of 
methods of the size reduction of microstrip hybrid branch-line couplers. Chun et al used lumped-distributed elements (open stubs) to obtain smaller sizes [1], while Jung et al in [2] and [3] transformed lines with distributed capacitors to use the inner area effectively. Recent authors' investigations also covered aspects of the design of small conventional microstrip branch-line couplers $[4,5]$.

As a reference structure for miniaturization one of the most common types of branch-line hybrid couplers was chosen. It consists of two $35 \mathrm{Ohm}$ transmission lines interconnected with $35 \mathrm{Ohm}$ line in the middle and two $120 \mathrm{Ohm}$ stubs at both ends of the structure at the same distance from the center. All lines should have the same phase response $90^{\circ}$.

The entire process of miniaturization consists of the replacement of the microstrip line with its equivalent in the form of a LPF with a $90^{\circ}$ phase difference at the central operating frequency. The proposed design is implemented on a substrate with a dielectric constant $\varepsilon=4.4$, dielectric loss tangent $\operatorname{tg} \delta=0.02$ and thickness $\mathrm{h}=1 \mathrm{~mm}$ with solid ground layer on the bottom.

As a result of this research, it was found that the dimensions of the resulting design are $41 \%$ less than of the conventional branch-line coupler and $66 \%$ less than of the conventional hybrid coupler.

Comparison of parameters of miniaturized hybrid coupler and the conventional one

\begin{tabular}{|c|c|c|c|c|c|}
\hline \multirow[t]{2}{*}{$\begin{array}{l}\text { Design and technologi- } \\
\text { cal implementation }\end{array}$} & \multirow[t]{2}{*}{$\begin{array}{l}\text { Area, } \\
\text { mm2 }\end{array}$} & \multirow{2}{*}{$\begin{array}{l}\text { Bandwidth with the } \\
\text { isolation level of } \\
-20 \mathrm{~dB}, \mathrm{MHz}\end{array}$} & \multirow[t]{2}{*}{$\begin{array}{l}\text { Phase dif- } \\
\text { ference }\end{array}$} & \multicolumn{2}{|c|}{$\begin{array}{c}\text { Transmission } \\
\text { coefficient }\end{array}$} \\
\hline & & & & $S_{31}$ & $S_{41}$ \\
\hline $\begin{array}{l}\text { Conventional branch-line } \\
\text { hybrid coupler }\end{array}$ & 1089.5 & 662 & 90.37 & -3.55 & -3.48 \\
\hline $\begin{array}{l}\text { Conventional branch-line } \\
\text { coupler }\end{array}$ & 627.08 & 223 & 90.24 & -3.46 & -3.49 \\
\hline $\begin{array}{l}\text { Proposed coupler with } \\
\text { 3rd order LPF }\end{array}$ & 370.45 & 695 & 89.65 & -3.77 & -3.4 \\
\hline
\end{tabular}

1. Young-Hoon Chun, Jia-Sheng Hong, IEEE MTT-S International Microwave Symposium Digest, 997 (2005).

2. Sung-Chan Jung, Renato Negra, Fadhel. M. Ghannouchi, Asia Pacific Microwave Conference, 1323 (2009).

3. Sung-Chan Jung, Renato Negra, Fadhel. M. Channouchi, IEEE Trans. Microw. Theory Tech., 56, 2950 (2008).

4. Letavin D.A., Mitelman Yu.E., Chechetkin V.A., 2015 Loughborough Antennas \& Propagation Conference, Loughborough, UK, DOI: 10.1109/LAPC.2015.7366013, (2015).

5. Letavin D.A., Mitelman Yu.E., Chechetkin V.A., 2015 International Conference on Microwaves, Communications, Antennas and Electronic Systems, Tel Aviv, Israel, DOI: 10.1109/COMCAS.2015.7360482, (2015). 